\title{
Is Sunscreen Decreasing Our Fertility?
}

\author{
Guarnizo-Poma Mirella ${ }^{1 *}$, Lázaro-Alcántara Herbert ${ }^{1}$ and Benites-Zapata Vicente Aleixandre ${ }^{2}$ \\ ${ }^{1}$ Instituto Médico de la Mujer/Instituto Médico Metabólico, Perú \\ ${ }^{2}$ Vicerrectorado de Investigación, Universidad San Ignacio de Loyola, Peru
}

Submission: April 04, 2018 ; Published: June 05, 2018

*Corresponding author: Mirella Guarnizo-Poma, Instituto Médico de la Mujer/Instituto Médico Metabólico, Av. Javier Prado Este 1476, San Isidro, Lima, Peru, Email: mguarnizo@imm.com.pe

\section{Opinion}

Currently, vitamin D deficiency is considered an epidemic disease that extends to many countries. The main reason for vitamin D deficiency is the lack of sun exposure in moderation given that it is the main source of vitamin D for most people. Foods are naturally lacking in vitamin D, and vitamin D fortified foods are often inadequate to meet daily vitamin D requirements. A circulating level of 25-hydroxyvitamin D of $>75 \mathrm{nmol} / \mathrm{L}$, or $30 \mathrm{ng} / \mathrm{mL}$, is needed to maximize the beneficial effects of vitamin $\mathrm{D}$ for health. In the absence of adequate sun exposure, at least 800-1000IU of vitamin D3/d may be needed to achieve this in children and adults [1]. We know that vitamin D deficiency causes rickets in children and will precipitate and aggravate osteopenia and osteoporosis unleashing fractures in adults. In addition, some epidemiological studies suggest that vitamin D deficiency is related to an increased likelihood of common cancers, autoimmune thyroid disease, hypertension and infectious diseases [2-5].

Vitamin D deficiency has been linked to a reduction in female fertility [6]. Some studies suggest that the underlying mechanism may be correlated with decreased levels of antiMüllerian ovarian hormone (AMH). Another mechanism involved is the relationship between vitamin D values and fertility is the decrease in the products of advanced glycation, insulin resistance and the value of free androgens, its relationship is inverse with BMI, and could be beneficial for the ovulation index and fertility. A recently published randomized double-blind clinical trial demonstrated that an acute high dose of vitamin D3 increased the AMH value of young women [7]. In addition, a cohort study showed that vitamin D3 deficiency is an independent predictor of ovulation and fertility in women with polycystic ovary in induction treatment with clomiphene [8].

On the other hand, a relationship between the hormonal alterations of fertility and chemical products has been proposed. Chemicals such as ethyl hexyl methoxy cinnamate (EHMC), benzophenone-3, phthalates and methyl- and ethyl paraben are considered endocrine disruptors chemicals (EDC) and are widely used in sunscreens, plastics, building materials, personal care products, insecticides and herbicides $[9,10]$. The EHMC is associated with antiestrogenic and/or antiandrogenic hormonal activities in fish exposed to water contaminated with sunscreen debris. There was a decrease in the sperm count and oogenesis, and other parameters were altered, such as biased sex ratio, immature gonads, decreased sexual activity, spawning reduction and infertility $[11,12]$. Likewise, exposure to EDC has been linked in recent animal studies with changes in various fertility parameters in exposed females and in their progeny. It was observed that chronic exposure to EDC, at environmentally relevant doses, modifies the reproductive parameters in female mice [13]. Human studies have shown that women exposed to EDC were up to 6 times more likely to be menopausal compared to non-exposed women [14]. Likewise, when the concentrations of EDC present in the serum were related to contamination of the follicular microenvironment, a decrease in the rate of fertilization and a lower probability of an oocyte becoming a high-quality embryo was found [15].

It has been suggested that the components in sunscreens mimic the effect of progesterone on the acrosome reaction and the penetration of sperm. Then, human exposure to these chemical UV filters could be detrimental to fertility by interfering with the function of the sperm, through the induction of a premature acrosome reaction [16]. In a cohort study in Chile, it was reported that the highest concentrations of monoethyl phthalate and triclosan were associated with earlier menarche among overweight or obese girls [17].

Due to the above findings it is advisable to teach patients about the damaging effect of the extremes, that is, the lack of total exposure to sunlight is as harmful as overexposure. It is necessary to define what should be the adequate state of vitamin $\mathrm{D}$ and the appropriate guidelines for solar exposure to UV radiation as well as for the proper use of sunscreens [18]. In that sense, it should be mandatory that public health campaigns on solar protection and dermatologists consider these findings 
in order to carry out large epidemiological studies that allow corroborating the relationship between the chemicals present in sun blockers and the decrease in fertility. On the other hand, until these findings are corroborated, consumers of sunscreens could be advised to be alert to ingredients such as ethyl hexyl methoxycinnamate and benzophenone-3, methyl and ethyl paraben and to suggest to the patient natural and chemicalfree sunscreens such as organic coconut oil when exposure to the sun is prolonged, given that a range of sun exposure without protection should not exceed 30 minutes, especially if the skin is Caucasian.

\section{References}

1. Holick MF, Chen TC (2008) Vitamin D deficiency: a worldwide problem with health consequences. Am J Clin Nutr 87(4): 1080S-1086S.

2. Wang J, Lv S, Chen G, Gao C, He J, et al. (2015) Meta-Analysis of the Association between Vitamin D and Autoimmune Thyroid Disease. Nutrients 7(4): 2485-2498.

3. Feldman D, Krishnan AV, Swami S, Giovannucci E, Feldman BJ, et al. (2014) The role of vitamin D in reducing cancer risk and progression. Nat Rev Cancer 14(5): 342-357.

4. Jeong HY, Park KM, Lee MJ, Yang DH, Kim SH, et al. (2017) Vitamin D and Hypertension. Electrolytes Blood Press 15(1): 1-11.

5. Kearns MD, Alvarez JA, Seidel N, Tangpricha V, Tangpricha V, et al. (2015) Impact of Vitamin D on Infectious Disease. Am J Med Sci 349(3): 245-262.

6. Luk J, Torrealday S, Perry NG, Pal L (2012) Relevance of vitamin D in reproduction. Hum Reprod 27(10): 3015-3027.

7. Dennis NA, Houghton LA, Pankhurst MW, Harper MJ, McLennan IS, et al. (2017) Acute Supplementation with High Dose Vitamin D3 Increases Serum Anti-Müllerian Hormone in Young Women. Nutrients 9(7): E719.

8. Ott J, Wattar L, Kurz C, Seemann R, Huber JC, et al. (2012) Parameters for calcium metabolism in women with polycystic ovary syndrome who undergo clomiphene citrate stimulation: a prospective cohort study. Eur J Endocrinol 166(5): 897-902.

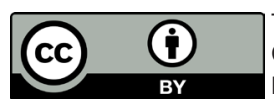

This work is licensed under Creative

Commons Attribution 4.0 License

DOI: 10.19080/JGWH.2018.10.555776
9. Rattan S, Zhou C, Chiang C, Mahalingam S, Brehm E, et al. (2017) Exposure to endocrine disruptors during adulthood: consequences for female fertility. J Endocrinol 233(3): R109-R129.

10. https://www.cdc.gov/exposurereport/index.html

11. Christen V, Zucchi S, Fent K (2011) Effects of the UV-filter 2-ethyl-hexyl4-trimethoxycinnamate (EHMC) on expression of genes involved in hormonal pathways in fathead minnows (Pimephales promelas) and link to vitellogenin induction and histology. Aquat Toxicol 102(3-4): 167-176.

12. Huang Y, Wang XL, Zhang JW, Wu KS (2015) Impact of endocrinedisrupting chemicals on reproductive function in zebrafish (Danio rerio). Reprod Domest Anim 50(1): 1-6.

13. Patiño-García D, Cruz-Fernandes L, Buñay J, Palomino J, Moreno RD, et al. (2018) Reproductive Alterations in Chronically Exposed Female Mice to Environmentally Relevant Doses of a Mixture of Phthalates and Alkylphenols. Endocrinology 159(2): 1050-1061.

14. Grindler NM, Allsworth JE, Macones GA, Kannan K, Roehl KA, et al. (2015) Persistent Organic Pollutants and Early Menopause in U.S. Women. PLOS ONE 10(1): e0116057.

15. Petro EML, Leroy JLMR, Covaci A, Fransen E, Neubourg DD, et al. (2012) Endocrine-disrupting chemicals in human follicular fluid impair in vitro oocyte developmental competence. Hum Reprod 27(4): 10251033.

16. Rehfeld A, Egeberg DL, Almstrup K, Petersen JH, Dissing S, et al. (2018) EDC IMPACT: Chemical UV filters can affect human sperm function in a progesterone-like manner. Endocr Connect 7(1): 16-25.

17. Binder AM, Corvalan C, Calafat AM, Ye X, Mericq V, et al. (2018) Childhood and adolescent phenol and phthalate exposure and the age of menarche in Latina girls. Environ Health 17(1): 32.

18. Reichrath J (2006) the challenge resulting from positive and negative effects of sunlight: how much solar UV exposure is appropriate to balance between risks of vitamin D deficiency and skin cancer? Prog Biophys Mol Biol 92(1): 9-16.

\section{Your next submission with Juniper Publishers will reach you the below assets}

- Quality Editorial service

- Swift Peer Review

- Reprints availability

- E-prints Service

- Manuscript Podcast for convenient understanding

- Global attainment for your research

- Manuscript accessibility in different formats

( Pdf, E-pub, Full Text, Audio)

- Unceasing customer service

Track the below URL for one-step submission https://juniperpublishers.com/online-submission.php 